\title{
Floral Radiometry: A Biophysical Basis to Characterize Landscapes.
}

\author{
R. Jaishanker ${ }^{1 *}$, N.P. Sooraj ${ }^{1}$, M. Somasekheran Pillai ${ }^{2}$, Athira. $\mathrm{K}^{1}$, Ammini Joseph ${ }^{3}$, \\ Aswathy Krishna ${ }^{1}$, Indu. $\mathrm{I}^{1}$ and Sarojkumar. $\mathrm{V}^{1}$ \\ 1. Department of Ecological Informatics, Indian Institute of Information Technology and \\ Management - Kerala, Trivandrum, 695581, India \\ 2. Department of Statistics, University College, Trivandrum, 695033, Kerala, India \\ 3. School of Environmental Studies, Cochin University of Science and Technology, Kalamassery, \\ 682022, Kerala, India
}

\begin{abstract}
This paper presents early results on studies of floral spectral reflectance of angiosperms and introduces floral radiometry as an emergent dimension of ecological research in India. Floral spectral reflectance of 121 angiosperm species was measured using hand-held spectroradiometer. The authors describe spectral reflectance of seven representative species within 350-800 nanometer region of the electromagnetic spectrum. Characteristic absorption and reflection of flowers, in ultraviolet and visible regions of the spectrum is reported. Near infrared reflectance was consistently high for all species studied. Flower color is unique to a species and importance of understanding flower color from pollinator's perspective is highlighted.
\end{abstract}

Keywords: Flower, Pigments, Reflectance, Color, Radiometry

\section{Introduction}

Flowers are Bill boards that plants use to attract pollinators. Floral coloration is the result of combined effect of light scattering by irregular cell complexes and wavelength selective absorbing pigments. Incoherently scattered light in the complementary wavelength determines the color of petals ${ }^{1}$. Deciphering flower color from a pollinator perspective is pivotal to floral biology, pollination studies and landscape ecology ${ }^{2-5}$. Floral radiometry presents a straightforward biophysical means to characterize landscapes and monitor temporal changes.

Potentials of radiometric studies of flowers were extensively discussed by Sir C.V. Raman during the $1960 \mathrm{~s}^{6-9}$.Whilst extensive studies have been carried out on flower color and plant pigments using light transmission technique (spectroscopy) ${ }^{10-13}$ there hardly exist any study on floral reflection in India. However numerous studies have been reported internationally ${ }^{14-18}$. Here the authors present the findings of the first radiometric studies of flowers in India.

\section{Study area and Methodology}

The study was carried out in Trivandrum, Kerala, India. Floral spectral reflection of 121 species of flowering angiosperms was measured in a dedicated campaign during February-March 2016. Situated between $8^{\circ} 17^{\prime} \mathrm{N}$ and $8^{\circ} 54^{\prime} \mathrm{N}$ latitudes and $76^{\circ} 41^{\prime} \mathrm{E}$ and $77^{\circ} 17^{\prime} \mathrm{E}$ longitudes, Trivandrum enjoys a 
tropical climate. The region falls in the Malabar phytogeographical province ${ }^{19}$ and harbors over 5000 species of flowering plants spread across 1500 genera and over 200 Families $^{20 \& 21}$.

Floral spectral reflectance were measured using hand-held spectroradiometer (Analytical Spectral Device, Inc. ASD Inc. Field spec $\left.{ }^{\circledR} 3\right)^{22}$. It records continuous reflected spectra from $350 \mathrm{~nm}$ to 2500 nm. All measurements were taken in fully open, healthy flowers. The field campaign was intentionally done on sunny days between 10:00 and 11:30 AM. Each floral spectral value recorded was a mean of 50 iterations aggregated across 15 samples of each species. Standard white reference correction was performed for each sample before and after recording. All reflectance spectra were processed using ASD View spec Pro for further analysis.

Quantitative analysis of spectral reflectance of representative violet, blue, yellow, orange, red, pink and white colored flowers were carried out using R stat. Details of the representative flowers selected for this study are indicated in Table1. Human perceived colors of flowers used for the study are illustrated in Figure 1. Spectral behavior of the representative flowers in Ultraviolet (UV); 350-399 nm, Blue (440-489 nm), Green (490-569 nm), Yellow (570-585 nm), Red (620-699 nm) and Near infrared (NIR) (700-800 nm) regions of electromagnetic spectrum constitutes findings of this study.

\section{Results and Discussion}

Table 2. summarizes the floral spectral reflectance of the seven species listed in Table 1. Characteristic floral spectral response curve of angiosperms used in the present study is depicted in Figure 2. It is interesting to note that all the seven flowers are highly reflective in the NIR region. At $28 \%$ Clitoria ternatea has the least and Lagerstromia speciosa (70\%), the highest NIR reflectance. Whilst strong UV absorption (98\%) was observed in Clitoria ternatea, Cassia fistula (20\%) and Cossandra infundibuliformis (17\%) reported high UV reflection. However UV reflection of Cossandra infundibuliformis showed a rising trend from 350 to $399 \mathrm{~nm}$ and Cassia fistula showed a decreasing trend.

Commelina benghalensis is a true blue reflecting flower. Lagerstroemia speciosa flower that appears pink to human observer absorbs almost equally green, yellow (89\% and 90\%) and absorbs slightly less in blue (79\%). It has a higher absorption in red (56.5\%). Human perceived color of Lagerstroemia speciosa is the complementary analogue resulting from absorption of blue, green and yellow. Hibiscus rosasinensis is characterized by its exponential increase in red reflection. It shows a mean reflection of $40 \%$ in red region. Flowers of Ipomoea carnea exhibits low to modest reflection across the entire spectrum studied.

It is evident from Table 2 that $60 \%$ of the flowers studied show a positive skew in their reflectance at lower end of spectrum. NIR reflectance in all species was skewed. Green and yellow floral reflectance of all species studied was normally distributed. Incoherently scattered light in the complementary 
wavelength determines color of flowers ${ }^{1}$. Flowers with blue absorbing carotenoid appear yellow and those with blue absorbing anthocyanin appear purple ${ }^{23}$. Specific reflection and absorption by flowers in the UV region indicates to the presence of chalcones/ alurones class of flavonoids ${ }^{24}$. Importance of UV absorption and reflection pattern in flowers was reported as early as $1894^{15}$. Specific pattern of floral reflectance (iridescence) governed by structured flower surface is vital for successful pollination 25

Floral reflectance spectrum was unique to all species studied. The spread of floral spectral reflection within each region of spectrum indicated by its skeweness points to the silent efforts made to attract pollinators. Differences in selective spectral absorption and consequent coloration were discussed by Sir C V Raman ${ }^{6-9}$. Nature has evolved flowers not to please man. It is a means to ensure plant evolution. Flower colors that we see around have evolved under selection by pollinators ${ }^{2 \& 5}$. It will be erroneous to classify flower colors as perceived by human beings, because major pollinators have evolved themselves into a different visual system with sensitivity to UV, blue and green ${ }^{4}$.

\section{Conclusion}

This paper describes floral spectral reflectance of seven visibly distinguishable flowers of Trivandrum and introduces floral radiometry as a sub-discipline of ecology in India. Discrepancy between floral reflection and color perceived by humans is distinct from the results. Floral spectral reflectance is unique to a species. It provides a measurable biophysical parameter to characterize landscape level changes.

\section{Acknowledgement}

Authors thank Dr. Rama Rao N, Associate Professor, IIST Trivandrum for providing spectroradiometer used in field measurement. We also thank Director, IIITM-K and Government of Kerala for facilitating and supporting this study.

\section{References}

1. Van der Kooi CJ, Wilts BD, Leertouwer HL, Staal M, Elzenga TM, Stavenga D G. Iridescent flowers? Contribution of surface structures to optical signaling. New Phytologist. 2014, (203), pp. 667-673.

2. Chittka L. Bee color vision is optimal for coding flower color, but flower colors are not optimal for being coded - why? Israel Journal of Plant Science. 1997, 45, pp. 115-127.

3. Peitsch DI, Fietz A, Hertel H, de Souza J, Ventura DF, Menzel R. The spectral input systems of hymenopteran insects and their receptor-based colour vision. Journal of Comparative Physiology A. 1992, 170, pp. 23-40.

4. Briscoe A D, Chittka L. The evolution of colour vision in insects. Annual Review Entomology. 2001, 46, pp. 471-510. 
5. Kevan PG, Baker HG. Insects as flower visitors and pollinators. Annual Review of Entomology. 1983, 28, pp. 407-453

6. Raman CV. The visual synthesis of colour. Current Science. 1964, 33, pp. 97-101. http://repository.ias.ac.in/69678/1/69678.pdf. Date accessed. 12/08/2016

7. Raman CV. Blue delphiniums and the purple bignonia. Current.Science. 1969; 38, pp. 553-554.

8. Raman CV. The pelargoniums. Current Science. 1970, 39, pp. 1-2.

9. Raman CV. Floral colours and the physiology of vision. Current Science.1963, 32, pp. 293-296.

10. Gronquist M, Bezzerides A, Attygalle A, Meinwald J, Eisner M, Eisner T. Attractive and defensive functions of the ultraviolet pigments of a flower (Hypericum calycinum). Proceedings of National Academy of Science. 2001; 98, pp. 13745-13750.

11. Sumathi R, Anuradha R. FT-IR Spectroscopic Studies on Flowers of Allamanda neriifolia Hook. International .Journal of Current Microbiolgy Applied Sciences. 2016, 56, 287-291.

12. Koldaev V, Manyakhin M, Zorikova O, Railko S, Kolyada A. Applying Numerical Indicators of Absorbance Spectrum to Evaluating Color of Flower Petals. Indian Journal of Science and Technology. 2016 June, 9(21), Doi no:10.17485/ijst/2016/v9i21/95191

13. Jadhav BA, Joshi AA. Extraction and Quantitative Estimation of Bio Active Component (Yellow and Red Carthamin) from Dried Safflower Petals. Indian Journal of Science and Technology. 2015 July, 8(16), Doi no:10.17485/ijst/2015/v8i16/42380

14. Chittka L, Menzel R. The evolutionary adaptation of flower colors and the insect pollinators' color vision systems. Journal of Comparative Physiology A. 1992, 171, pp. 171-181.

15. Chittka L, Shmida A, Troje N, Menzel R. Ultraviolet as s component of flower reflections, and the colour perception of Hymenoptera. Vision Res. 1994 June; 34 (11), pp. 1489-1508.

16. Van der Kooi CJ, Elzenga TM, Staal M, Stavenga DG. How to colour a flower: On the optical principles of flower coloration. Proceedings of the Royal Society B. May 2016, 283, pp. 1-9.

17. Menzel R, Shmida A. The ecology of flower colours and the natural colour vision of insect pollinators: The Israeli flora as a study case. Biological Reviews. 1993, 68, pp. 81120.

18. Kay QON, Daoud HS, Stirton CH. Pigment distribution, light reflection and cell structure in petals. Botanical Journal of the Linnean Society. July 1981, 83(1), pp. 57-83.

19. Takhtajan A. Floristic Regions of the World. University of California Press. Berkeley, 1986.

20. Nayar TS, Rasiya Beegam A, Mohanan N, Rajkumar G. Flowering Plants of Kerala - A Handbook. TBGRI, Thiruvananthapuram, 2006.

21. Sasidharan, N. Flowering Plants of Kerala - Version 2.0. DVD No. 14. Kerala Forest Research Institute. Peechi, 2012.

22. ASD FieldSpec ${ }^{\circledR} 3$ User Manual. http://support.asdi.com/Document/Viewer.aspx?id=108 Date Accessed: 19/07/2016.

23. Grotewold E. The genetics and biochemistry of floral pigments. Annual Review of Plant Biology. 2006, 57, pp. 761-780.

24. Lattanzio V, Lattanzio VMT, Cardinali A. Role of phenolics in the resistance mechanisms of plants against fungal pathogens and insects. In: Phytochemistry: Advances in Research. F. Imperato (ed.), Research Signpost. Trivandrum. 2006, pp. 23-65. 
25. Whitney HM, Kolle M, Andrew P, Chittka L, Steiner U, Glover BJ. Floral iridescence, produced by diffractive optics, acts as a cue for animal pollinators. Science. 2009, 323, pp. 130-133. 
Table 1 Details of selected flowers used for the present study

\begin{tabular}{|l|l|l|l|}
\hline No & \multicolumn{1}{|c|}{ Species } & \multicolumn{1}{c|}{ Family } & \multicolumn{1}{c|}{$\begin{array}{c}\text { Human perceived } \\
\text { Flower Color }\end{array}$} \\
\hline 1 & Clitoria ternatea & Fabaceae & Violet \\
\hline 2 & Commelina benghalensis & Commelinaceae & Blue \\
\hline 3 & Cassia fistula & Fabaceae & Yellow \\
\hline 4 & Crossandra infundibuliformis & Acanthaceae & Orange \\
\hline 5 & Hibiscus rosasinensis & Malvaceae & Red \\
\hline 6 & Lagerstroemia speciosa & Lythraceae & Pink \\
\hline 7 & Ipomoea carnea & Convolvulaceae & White \\
\hline
\end{tabular}


Table 2. Spectral region wise statistical parameters of floral reflectance

\begin{tabular}{|c|c|c|c|c|}
\hline Species & $\begin{array}{c}\text { Spectral } \\
\text { Region }\end{array}$ & $\begin{array}{c}\text { Mean Floral Reflection } \\
(\%) \text { (Min. Max) }\end{array}$ & $\begin{array}{l}\text { SD } \\
(\%)\end{array}$ & $\begin{array}{c}\text { Skewness } \\
\text { z score }\end{array}$ \\
\hline \multirow{6}{*}{ Clitoria ternatea } & UV & $1.8(0.8,4.3)$ & 1 & $3.080^{*}$ \\
\hline & Blue & $8.5(7.8,8.9)$ & 0.3 & $-2.080^{*}$ \\
\hline & Green & $6.1(5,7.7)$ & 0.7 & 2.468 \\
\hline & Yellow & $4.8(4.8,4.9)$ & 0.05 & 1.488 \\
\hline & Red & $11.3(4.4,19.5)$ & 5.2 & -0.108 \\
\hline & NIR & $28.2(19.7,32)$ & 3.7 & $-3.625^{*}$ \\
\hline \multirow{6}{*}{ Commelina benghalensis } & UV & $7.3(4.2,13.6)$ & 2.9 & $2.214^{*}$ \\
\hline & Blue & $17.4(14.2,19.6)$ & 1.7 & -1.202 \\
\hline & Green & $10.4(6.9,14.1)$ & 1.9 & 0.175 \\
\hline & Yellow & $6.1(5.5,6.8)$ & 0.4 & 0.539 \\
\hline & Red & $11.2(7.7,21.8)$ & 4.1 & $4.123^{*}$ \\
\hline & NIR & $39.8(22.4,45.6)$ & 6.9 & $-4.733^{*}$ \\
\hline \multirow{6}{*}{ Cassia fistula } & UV & $14(7.7,19.3)$ & 3.8 & -0.448 \\
\hline & Blue & $4.3(3.9,5.4)$ & 0.4 & $3.567^{*}$ \\
\hline & Green & $19.8(5.6,26.27)$ & 7.2 & -2.799 \\
\hline & Yellow & $25.4(25.1,25.74)$ & 0.2 & 0.323 \\
\hline & Red & $22.2(20.8,24.76)$ & 1 & 0.937 \\
\hline & NIR & $31.7(25,33.55)$ & 2.4 & $-5.246^{*}$ \\
\hline \multirow{6}{*}{$\begin{array}{l}\text { Crossandra } \\
\text { infundibuliformis }\end{array}$} & UV & $17.3(10.9,20.5)$ & 3 & $-2.234^{*}$ \\
\hline & Blue & $8.1(6.9,10.3)$ & 0.9 & $2.499^{*}$ \\
\hline & Green & $15.6(7.3,26.6)$ & 7.12 & 1.401 \\
\hline & Yellow & $29.8(26.9,33.2)$ & 2.1 & 0.246 \\
\hline & Red & $44.8(44.1,46.9)$ & 0.5 & $5.699^{*}$ \\
\hline & NIR & $56.3(47.1,59.6)$ & 3.9 & $-4.379^{*}$ \\
\hline \multirow{6}{*}{ Hibiscus rosasinensis } & UV & $7.5(4,10.2)$ & 1.9 & -1.142 \\
\hline & Blue & $7.1(6.5,7.5)$ & 0.3 & -0.395 \\
\hline & Green & $7(6.3,8.3)$ & 0.6 & 1.316 \\
\hline & Yellow & $9.2(8.4,10.3)$ & 0.6 & 0.537 \\
\hline & Red & $38.1(24.2,49.5)$ & 6.2 & -1.855 \\
\hline & NIR & $67.7(50.1,72.8)$ & 6.7 & $-5.096^{*}$ \\
\hline \multirow{6}{*}{ Lagerstroemia speciosa } & UV & $4.7(3.5,10.2)$ & 1.7 & $5.558^{*}$ \\
\hline & Blue & $19.8(15.5,22.4)$ & 2.1 & -1.650 \\
\hline & Green & $11(9.2,15.3)$ & 1.8 & 3.175 \\
\hline & Yellow & $10.7(9.8,11.7)$ & 0.6 & 0.645 \\
\hline & Red & $43.5(28.3,54.9)$ & 6.3 & -2.175 \\
\hline & NIR & $68.4(55.6,72.2)$ & 4.6 & $-5.642^{*}$ \\
\hline \multirow{6}{*}{ Ipomea carnea } & UV & $6.1(4.5,7.6)$ & 1 & -0.510 \\
\hline & Blue & $3.5(3.4,3.9)$ & 0.1 & $3.674^{*}$ \\
\hline & Green & $10.1(3.9,17.2)$ & 5 & 0.758 \\
\hline & Yellow & $17.1(17,17.2)$ & 0.05 & -1.626 \\
\hline & Red & $16.1(15.3,18.9)$ & 0.8 & $5.413^{*}$ \\
\hline & NIR & $31.6(19.2,35.9)$ & 5.2 & $-4.338^{*}$ \\
\hline
\end{tabular}

* indicates skewed distribution 
bioRxiv preprint doi: https://doi.org/10.1101/088583; this version posted November 18, 2016. The copyright holder for this preprint (which was not certified by peer review) is the author/funder, who has granted bioRxiv a license to display the preprint in perpetuity. It is made available under aCC-BY-NC-ND 4.0 International license.
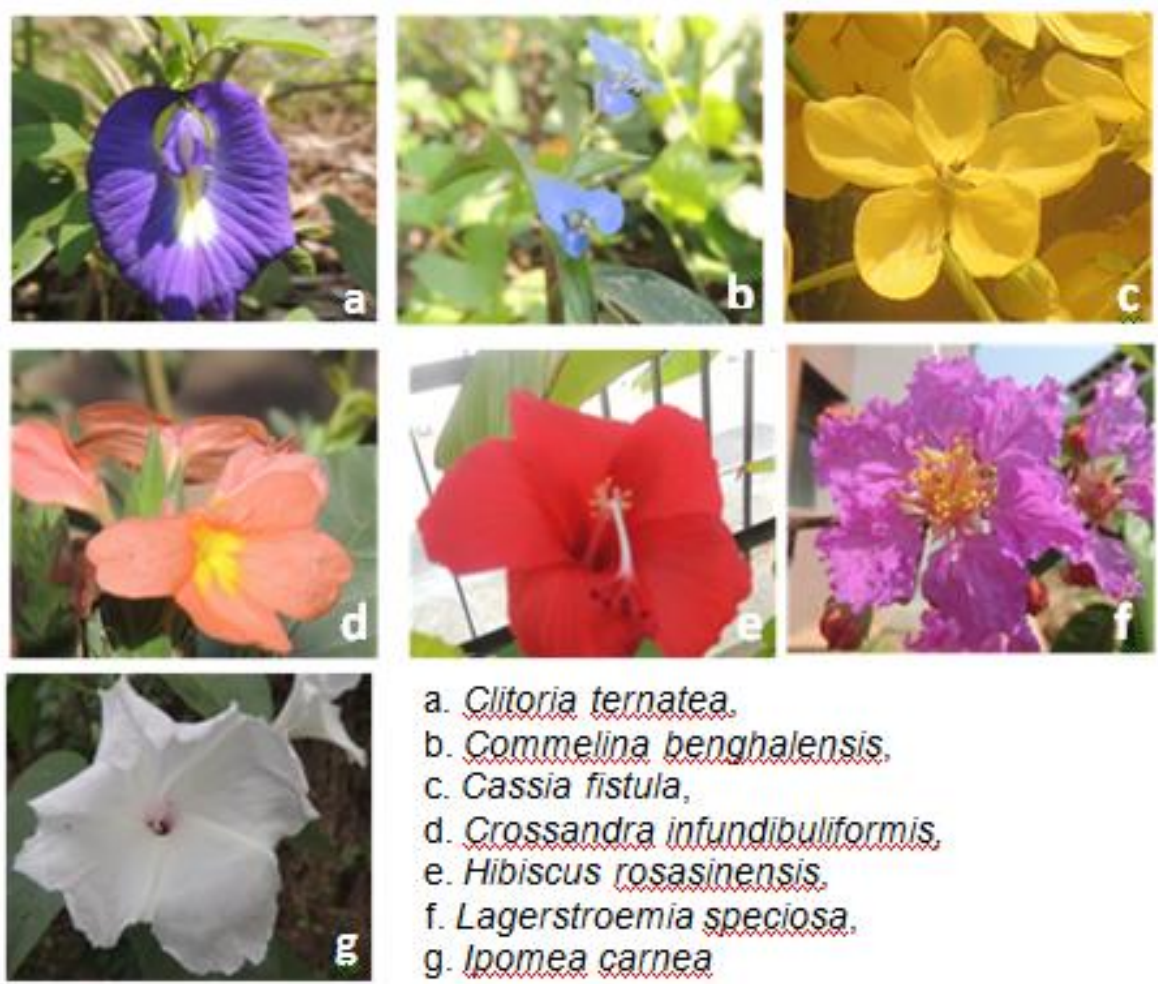
a. Clitoria ternatea,
b. Commelina benghalensis,
c. Cassia fistula,
d. Crossandra infundibuliformis,
e. Hibiscus rosasinensis,
f. Lagerstroemia speciosa,
g. Ipomea carnea

Figure 1(a-g) Species name and human perceived color of flowers 
bioRxiv preprint doi: https://doi.org/10.1101/088583; this version posted November 18,2016 . The copyright holder for this preprint (which was not certified by peer review) is the author/funder, who has granted bioRxiv a license to display the preprint in perpetuity. It is made available under aCC-BY-NC-ND 4.0 International license.

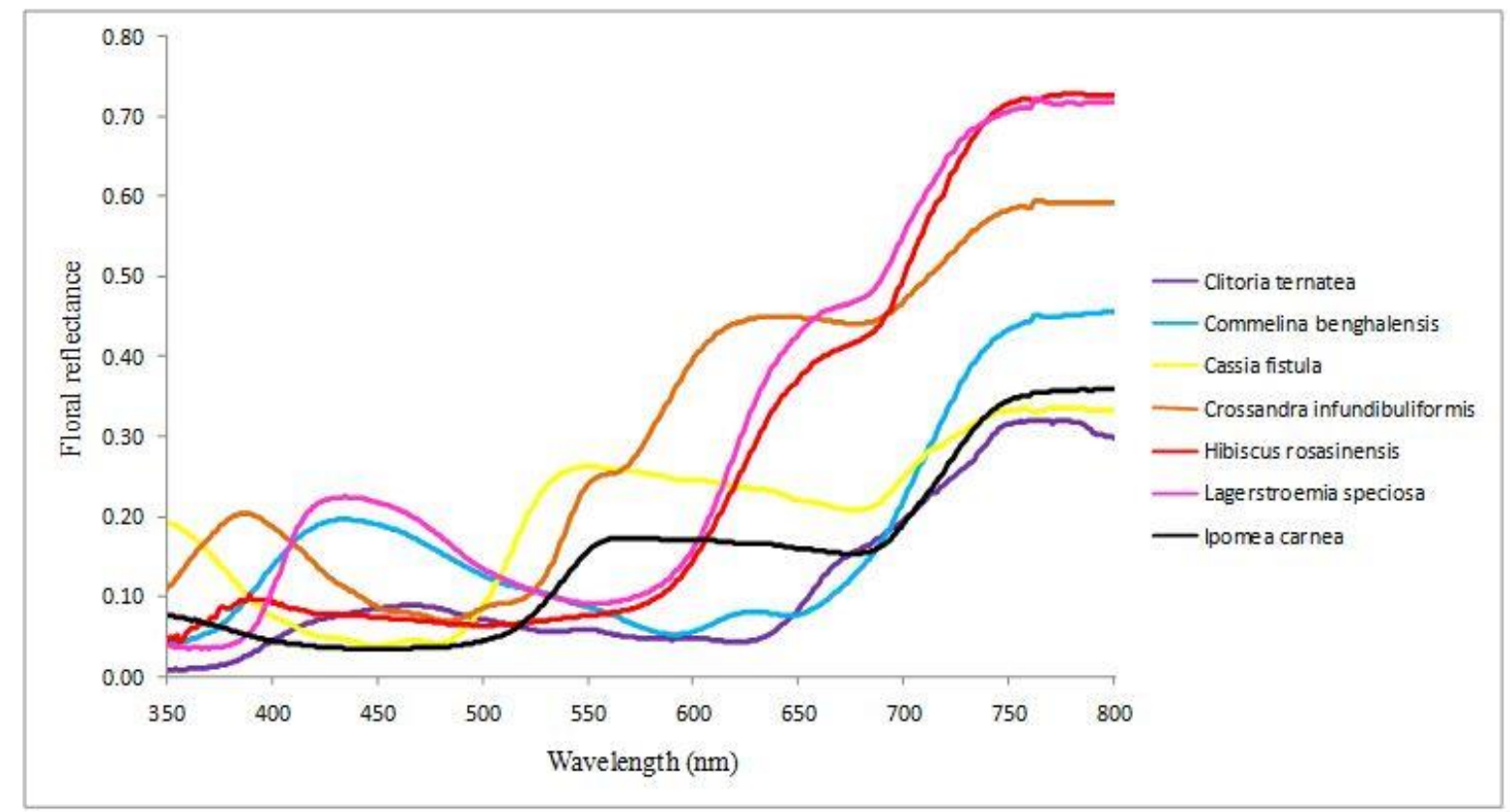

Figure 2 Spectral response curves of flowers 